\title{
MeSO-net 連続地震観測記録にみられる \\ 関東平野西端部による盆地端部生成波の伝播特性 \\ PROPAGATION CHARACTERISTIC OF THE BASIN EDGE INDUCED WAVE AT THE WESTERN EDGE OF THE KANTO BASIN OBSERVED FROM THE CONTINUOUS RECORD OF MeSO-net
}

\author{
地 元 孝 輔*1
}

\section{Kosuke CHIMOTO}

\begin{abstract}
The generation process and propagation of the basin edge induced wave were observed from the continuous ground motion record by MeSO-net. The basin edge induced wave was generated at the western edge of the Kanto basin when S-wave, generated near Choshi City, arrived there. Particle motion revealed that Love wave dominates in the transverse components, while the higher mode of Rayleigh wave dominates in vertical motion. Snapshot enables to visualize the marriage of the basin edge induced wave and direct surface wave. Numerical simulation reproduced the observed basin edge induced wave. That wave significantly amplifies the displacement response.
\end{abstract}

Keywords : Basin edge induced wave, Basin edge transduced wave, Kanto basin, Surface wave, Long period ground motion, MeSO-net 盆地端部生成波, 盆地端部転換波, 関東平野, 表面波, 長周期地震動, MeSO-net

1. はじめに

大規模な堆積層により形作られた堆積平野の盆地端部は，盆地端 部生成波や盆地端部転換波を生み出す。それらは特徵的な地震動の 生成と, エッジ効果による被害分布の形成に直結している。そのた め盆地端部生成波と転換波を理解すること, ひいては盆地端部構造 を明らかにすることは ESG (Effect of surface geology on seismic motion）研究において古くから重要な課題となっている。川瀬 (1993) 1)による定義では, 盆地生成表面波とは, 震源から盆地周辺部 までは実体波として伝播し盆地端部で表面波になったものである。 1985 年メキシコミチョアカン地震や 1995 年兵庫県南部地震で注目 されたが, 同じような盆地端部構造であればどこでも発生しうる普 遍的な現象である(川瀬, $\left.1993{ }^{1}\right)$ )。当時は限られた観測記録と被害分 布の特徴(Kawase, $\left.1996^{2)}\right)$, そして当時最先端であった $2 \cdot 3$ 次元シ ミュレーション(例えば, Kawase and Aki, 1989 3) によりその存在 が証明された。その後わが国では K-NET や KiK-net という強震観 測網が構築され(NIED, 2019 4), 各自治体でも震度計測を始めるよ うになったことから，数多くの強震観測記録が蓄積されてきた。一 方, 盆地転換表面波は, 震源から盆地端部まで表面波として伝播し, 盆地端部で変換・増幅されて盆地内を往復する表面波である（川瀬, $1993^{11)}$ 。特に大規模な関東平野一入射した表面波が励起した盆地端 部転換表面波が観測されており，2004 年紀伊半島沖地震(Miyake and Koketsu, 2005 5)) や 2004 年中越地震 (Furumura and Hayakawa, 2007 6))の際には, 関東平野において盆地端部で転換さ れた長周期地震動が伝播する様子が直接観測された。しかし, 実体 波が盆地端部に入射して生成される盆地端部生成波が盆地内を震源
に向かって後戻りする方向に伝播する様子は明瞭には確認されてい ないようである。

日本全国の主要な強震観測網である K-NET や KiK-net の観測点 間隔は $20 \mathrm{~km}$ 程度であるが, 首都直下プロジェクトにより構築され た MeSO-net は関東平野において $2-10 \mathrm{~km}$ 間隔で設置されている (Aoi et al., 2020 7))。この MeSO-netは, 従来の強震観測では一般 的なトリガー式とは異なり, 連続観測という特徴がある(酒井・平田, 2009 8)。そそのため, 連続観測記録を利用した地震波干渉法への適用 が行われている(例えば, Denolle et al., 2014 9); Viens et al., 2016 10)）。Boué et al. (2016) 11)は，仮想震源により合成した関東平野内の 地震波動伝播について検討した。それにより，表面波が関東平野西 端において明瞭に反射する様子を捉え, さらに高次モードのレイリ 一波とラブ波が関東平野を伝播する複雑な特性も捉えた。このよう に Boué et al. (2016) 11) は，MeSO-netによる高密度な連続観測とい う特徵を生かして, 盆地端部が波動伝播に与える影響について, 地 震波干渉法による仮想地震記録により見事に可視化した。仮想地震 の合成波形に明瞭にみられる盆地端部における反射波は，当然実際 の地震において顕在化するものと考えられる。ところが，盆地端部 で反射した波は関東平野を 5 分以上かけて往復する。そのため, 従 来のトリガー式強震観測では後続波まで記録されないことがある。 そこで本研究では，MeSO-netの観測記録を利用することにより， 十分な記録長の地震動について検討することと, そして何より首都 圏における高密度な観測によって, 実地震による盆地端部生成波の 生成メカニズムと関東平野内の波動伝播特性について検討する。

*1 香川大学創造工学部 准教授・博士 (工学)

Assoc. Prof., Faculty of Engineering and Design, Kagawa Univ., Dr.Eng. 


\section{2. 観測記録}

\subsection{0 年 6 月 25 日銚子市付近の地震波形}

MeSO-net は首都圈に展開された約 400 点からなる中感度地震観 測網である(酒井・平田, 2009 8))。WIN フォーマット形式で $200 \mathrm{~Hz}$ サンプリングの連続観測が行われている。センサーは日本航空電子 工業製サーボ型加速度計 JA-40GA-02 である。人工ノイズを極力 軽減するため地中 $20 \mathrm{~m}$ に設置されているが，本稿では周期 1 秒以 上かほとんどは周期 3 秒以上に着目するので，地表の観測記録とみ なせるものとする。

Fig. 1 a)には 2020 年 6 月 25 日銚子市付近の地震 $M 6.0$ の気象庁 一元化震源による震央位置とメカニズム解を示している。この地震 の震央距離およそ $160 \mathrm{~km}$ のところに八王子構造線(Hachioji Tectonic Line; HTL)が南北方向に直線的に存在しており, HTL に 地震波が到達する頃には, 波面はおよそ平面に近くなって見える。

MeSO-net の観測記録のうち, 赤で示した観測点で観測された加 速度記録を積分して推定した速度波形を Fig.2 に示す。振幅はそれ ぞれの波形で規格化されている。震源と観測点位置の関係から, NS 成分はほぼトランスバース成分, EW 成分はラディアル成分とみな すことができる。周期 3-9 秒のフィルタを施した NS 成分の速度波 形には, 約 60 秒後に HTL に到達し, その後震源に向かって逆戻り する明瞭な波群が確認できる (Fig.2a 中央の緑色矢印(2)）。発震後 HTL に向かう $\mathrm{S}$ 波の伝播速度は約 $3 \mathrm{~km} / \mathrm{s}$ であるが，逆方向に伝播 する波の速度はそれよりも遅いことが読み取られ，伝播速度の違い から， $\mathrm{S}$ 波とは異なる波に変換したことが推測される。このように 盆地端部で変換される波は, 盆地端部生成波や盆地端部転換波とし て知られている(川瀬, 1993 1)。この場合, $\mathrm{S}$ 波が盆地端部によって 表面波に変換していると考えられるため, 盆地端部生成表面波とい え，トランスバース成分であることを考えるとラブ波の可能性が高 い。この点について後に数值シミュレーションにより議論するほか, 伝播速度が $0.5 \mathrm{~km} / \mathrm{s}$ 程度であることから, 基本モードのラブ波の速 度と一致している（付録の Fig.A1b 参照）。それとここで改めて強 調したいのは, Fig.2 の横軸は地震発生から 450 秒後までを示して

a)

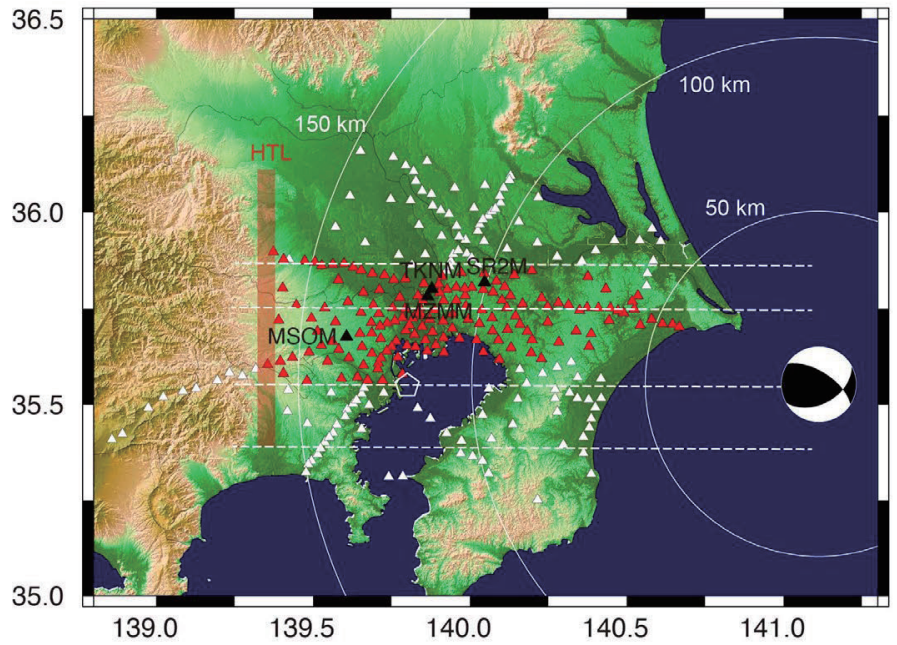

おり，通常の強震観測記録に比べて格段に長く，トリガー観測では 記録が終了している可能性がある範囲であり，連続観測の長所が生 きている。

NS 成分に見られるこの盆地端部生成表面波は，上下と EW 成分 においても確認でき（Fig.2a 左，左から 3 番目の矢印と, Fig.2a 右, 左から 2 番目の矢印), これらの成分はレイリー波である可能性が 高い。上下成分にはさらに, 300 秒後に HTL に到達する直達表面 波が確認され (Fig.2a 左, 左から 4 番目の矢印), それが HTL から 伝播方向を変えて震源に向かって類似した速度で伝播している波が 確認される（Fig.2a 左，左から 6 番目の矢印）ことから，これは盆 地端部転換表面波といえる。さらに上下成分においては, 約 180 秒 後に高次モードと考えられるレイリー波が明瞭に確認でき（Fig.2a 左, 左から 2 番目の矢印), それが HTLによってそれよりも遅い速 度で伝播している（Fig.2a 左，左から 5 番目の矢印）こと，すなわ ち基本モードのレイリー波に転換したものと考えられる。このよう に高次モードが現れることは Kawase and Aki (1989) 3)において P$\mathrm{SV}$ 波動場のシミュレーションで指摘されたことと同じことが実際 の地震観測記録にも確認できる。この高次モードは, Boué et al. (2016) 11)による仮想地震記録においても明瞭に確認されている。こ れらの 3 つの盆地端部生成波と転換波は同じ速度で伝播しているこ とから同じ種類の地震波といえる。

ところで Boué et al. (2016) 11)は，地震波干渉法により仮想地震波 形を合成しており，仮想地表震源で発生した表面波が HTL に到達 した後，伝播方向を変えて同様の速度で伝播していることから，盆 地端部転換波が明瞭に見えている。Boué et al. (2016) 11)では，この 波を”reflected wave”とよんでいるが，冒頭に示したとおり，盆地端 部生成波や盆地端部転換波を識別することは地震工学にとって重要 である。この波はわずかながら実際の地震観測波形に見られるもの (Fig.2a 左の矢印(6) と同じであると考えられる。しかし, Fig.2の地 震観測波形に顕著に見られる $\mathrm{S}$ 波から表面波に変換した盆地端部生 成波が，Boué et al. (2016) 11)の仮想地震波形にはほぼ見られない。 これは，地震波干渉法により合成される仮想地震記録の実体波は，

b)

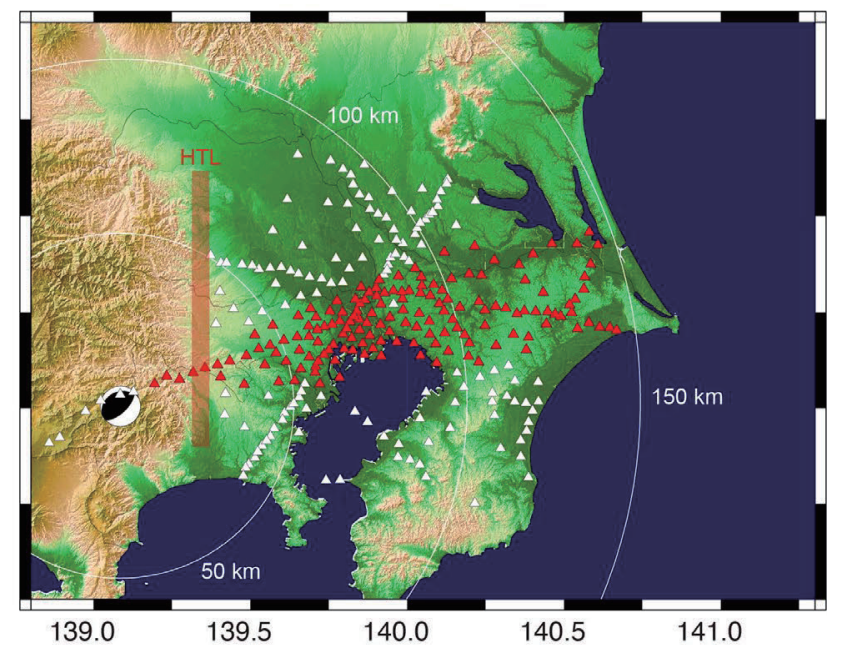

Fig.1 Location of the epicenters of the 2020 M6.0 near Choshi City a) and the 2019 M4.3 eastern Yamanashi Prefecture b). Triangle indicates the location of MeSO-net ${ }^{8)}$ stations. Red and black triangles are chosen for plotting the waveforms in Figs. 2 and 3 . Black triangle indicates the station selected for the calculation of response. Approximate position of the Hachioji Tectonic Line (HTL) is shown by red. Pentagon is the location of the model extracted for calculation of surface wave. White broken line is a section for the $2 \mathrm{D}$ simulation. 

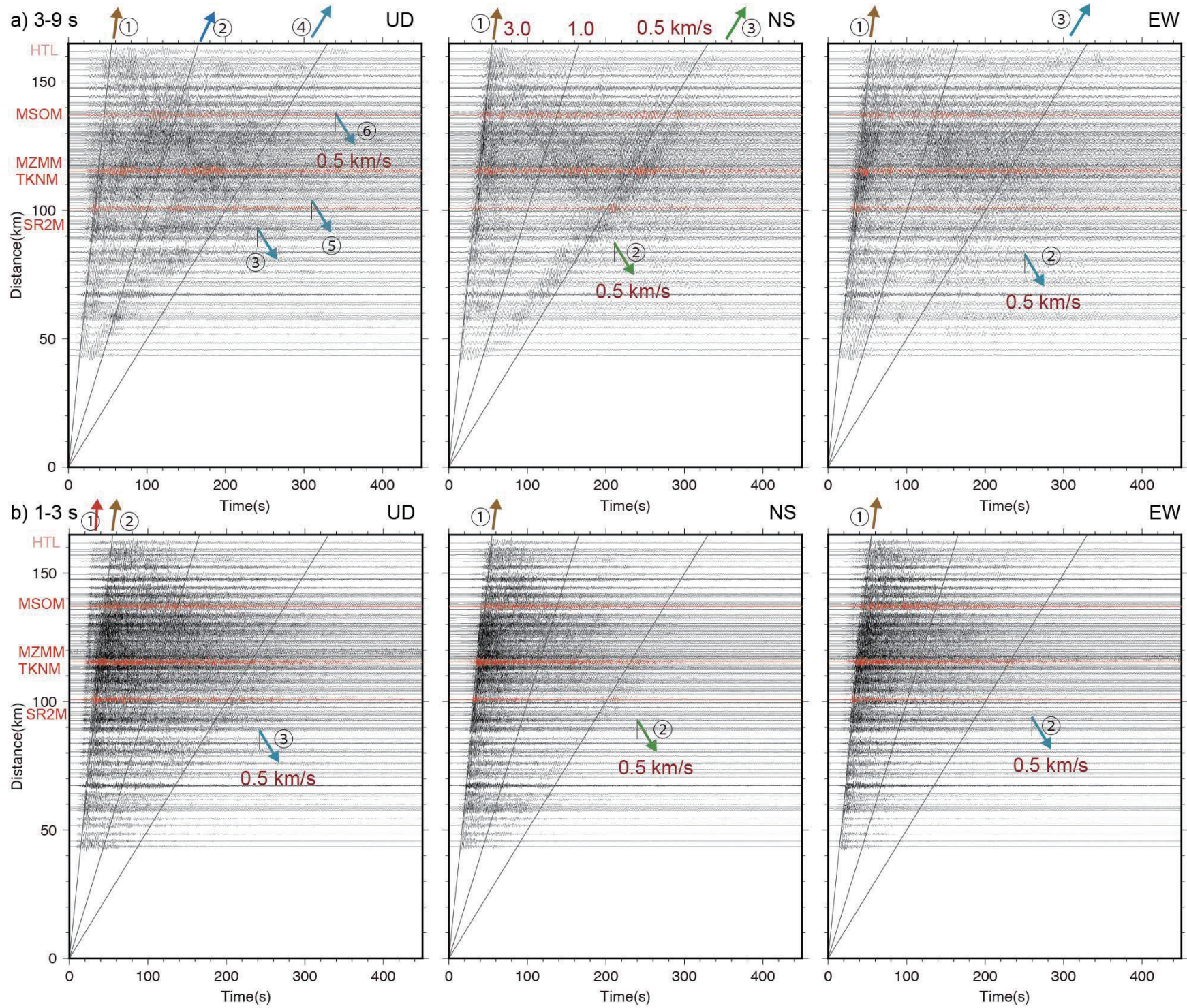

Fig.2 Velocity waveform observed by the MeSO-net during the event of the 2020 M 6.0 near Choshi City. The stations are selected as shown in Fig.1a. Red trace indicates the waveform observed at the northwestern part of Chiba Prefecture (SR2M), Misato City (MZMM) and Kanamachi, Katsushika Ward (TKNM) in the Tokyo lowland area and Suginami Ward (MSOM) at Musashino Plateau. Bandpass filter ranges of a) 3-9 s and b) 1-3 s were used. Distinct wave propagation is indicated by arrow. Direct P-wave and S-wave are indicated by red and brown colored arrows, while the fundamental modes of Rayleigh-wave and Love-wave are indicated by light blue and green. The first higher mode of Rayleigh-wave is colored by dark blue.

過小評価され，表面波がより強調されることによるものと考えられ る(Forgani and Snieder, 2010 12))。また，震源が浅ければ表面波が 卓越しや寸いことも挙げられる。この点についても後に数值シミュ レーションにより確認する。

Fig.2 b) は周期 1-3 秒でフィルタを施した速度波形である。より 高周波成分であることから実体波が強調されており，上下成分には $\mathrm{P}$ 波が明瞭に確認され, 水平成分には明瞭な $\mathrm{S}$ 波が確認される。直 達表面波はわずかに上下と NS 成分に見られる。そのため, 盆地端 部転換波はほとんど確認できない。一方, $\mathrm{S}$ 波が到達した後, 周期 3-9 秒の波形に見られた盆地生成表面波はそれほど明瞭ではないも のの, 盆地端部表面波として到達するであろうと期待される時間に おいてペーストアップの密度が高くなっている（Fig.2b 左，(3)の矢 印, 中央, 右(2)の矢印)。
このように, この地震による観測記録には, 関東平野西端部によ る盆地端部生成波が明瞭に含まれていることがわかった。上下動は, 地震発生 3 分後に東京低地(MZMM や TKNM) で基本モードの直達 レイリー波と盆地端部生成レイリー波が融合する。水平動について は, NS 成分では 210 秒後に千葉県北西部(SR2M)で基本モードの直 達ラブ波と盆地端部生成ラブ波が融合する。東京都心(震央距離 120 130km) では，地震発生 1 分以内に震源からの直達 $\mathrm{S}$ 波が到達 し, 3 分後には盆地端部生成ラブ波, 4 分後に震源方向から直達ラ ブ波が到達するため, 3 度の大きな摇れが観測されている。

\subsection{9 年 7 月 8 日山梨県東部の地震波形}

さきほどの観測記録に見られた盆地端部生成波について，特に NS 成分は緩やかにカーブを描いているようにも見える（Fig.2a 中 


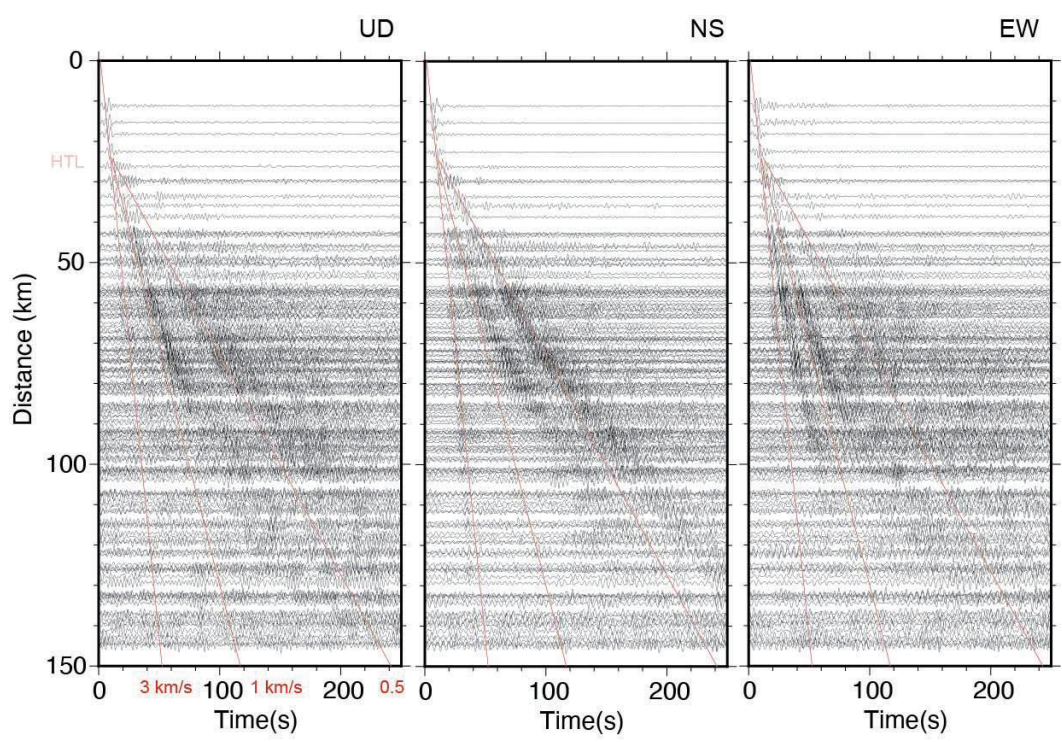

Fig.3 Velocity waveform observed by the MeSO-net during the event of the 2019 M 4.3 eastern Yamanashi Prefecture. The stations are selected as shown in Fig.1 b. Bandpass filter range of 3-9 s was used.

央, 左から 2 番目の矢印)。関東平野の地下構造は一様ではないので 表面波の伝播特性も一様でないことは容易に予想される。そこで Fig. 3 は, 2019 年 7 月 8 日山梨県東部の地震 $M 4.3$ により, Fig.1 b)に示された観測点の記録を示している。地震発生約 10 秒後およ そ $25 \mathrm{~km}$ で HTL に到達して盆地端部生成波あるいは盆地端部転換 波と思われる表面波に転換してその後関東平野内を伝播している様 子が全成分にうかがえる。しかも，2 本のブランチを持ちそれらが 綺麗なカーブを描いている。すなわち伝播速度が徐々に遅くなって いることを示しており, 平野中心部に向かって堆積層の $\mathrm{S}$ 波速度が
遅くなっていること，あるいは堆積層が厚くなっていることが影響 しているものと考えられる。

2 本のブランチの生成過程は観測記録だけから推定することは難 しいが，上下成分では伝播速度が異なっていることはレイリー波の モードの違う波である可能性が高い。EW 成分では高次モードが卓 越していることから，レイリー波の楕円率によって決まるものと考 えられる(付録の Fig.A2a,d)。NS 成分のラブ波では類似した速度で 2 本のカーブを描いていることから, $\mathrm{S}$ 波が変換した盆地端部生成 波と，表面波が変換した盆地端部転換波の可能性がある。この 2 本

a) $50 \mathrm{~s}$
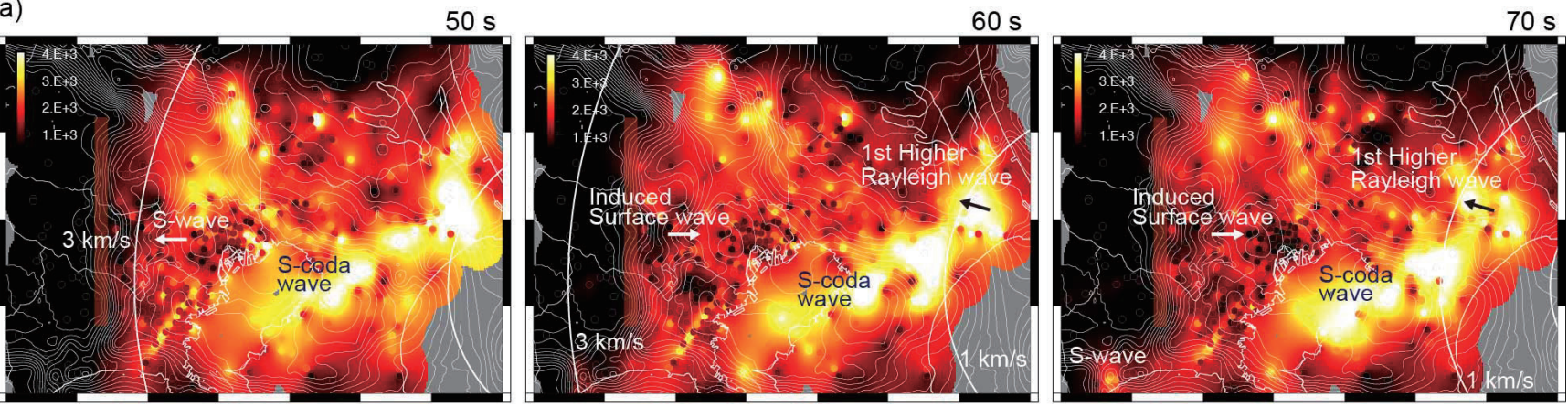

b)
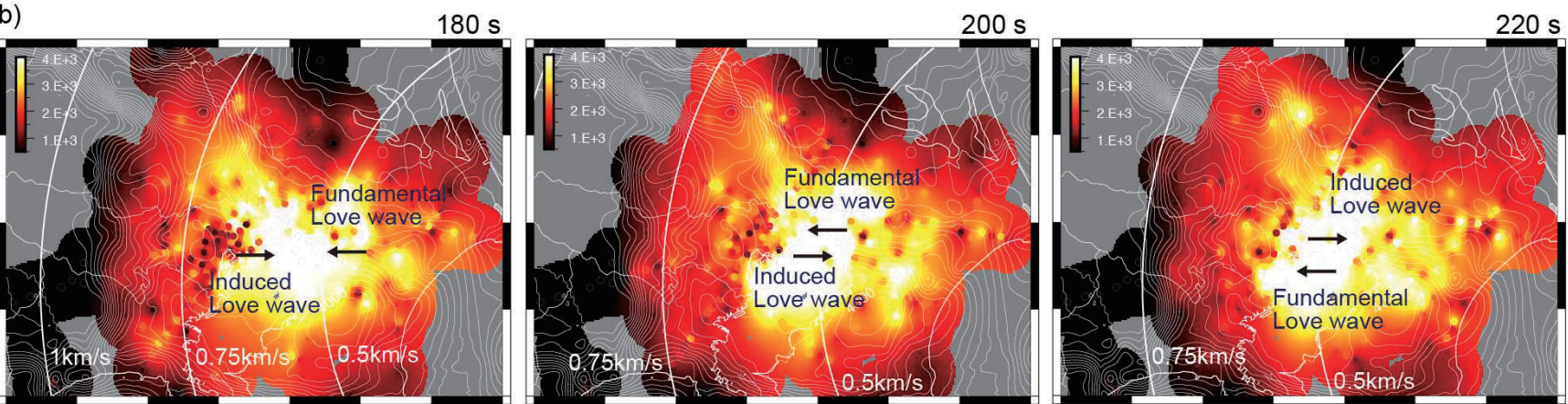

Fig.4 a) Square root of seismic kinetic energy for $10 \mathrm{~s}$ around times of 50,60 and $70 \mathrm{~s}$ after the origin time. Direct S-wave arrives at the western edge of the Kanto basin and the first higher mode of Rayleigh wave is observed inside the basin. Kinetic energy around times of 180,200 and $220 \mathrm{~s}$ are shown in b). Marriage of induced and direct surface waves is observed at the center of the basin. Approximate position of the Hachioji Tectonic Line (HTL) is shown by red. The contour indicates the depth to the seismic bedrock by JIVSM ${ }^{14)}$. 


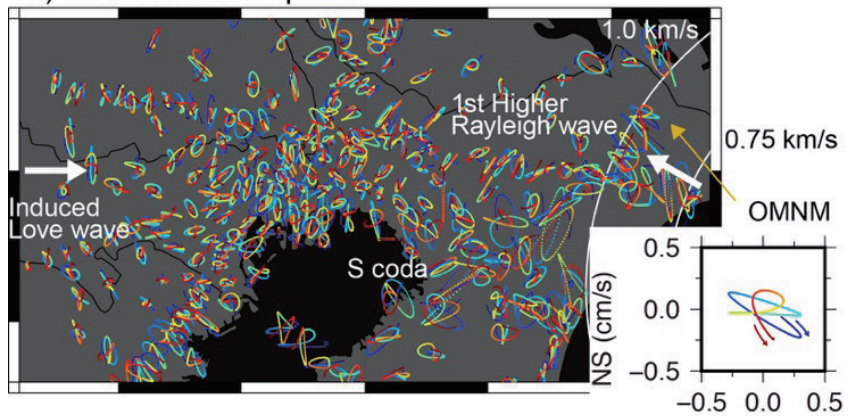

c) $200 \mathrm{~s}$ Horizontal-plane

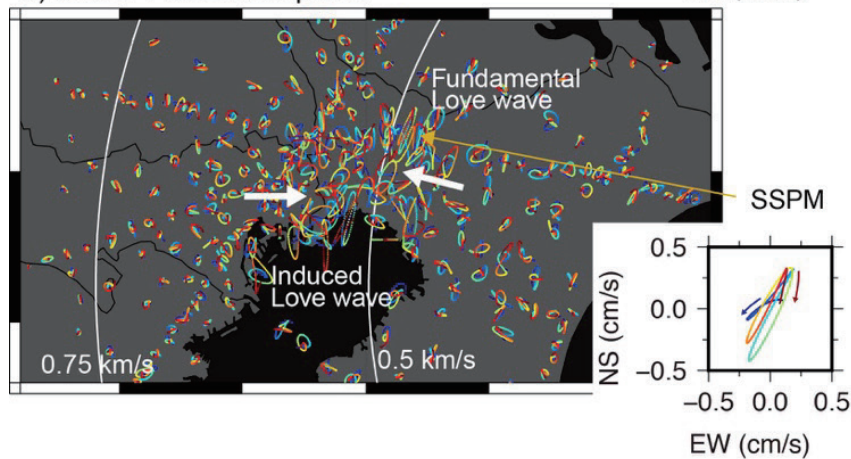

b) $60 \mathrm{~s}$ Vertical-plane

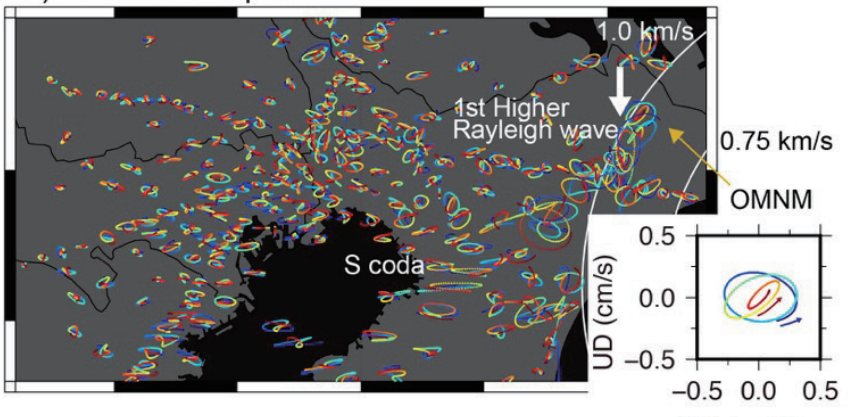

$\mathrm{EW}(\mathrm{cm} / \mathrm{s})$

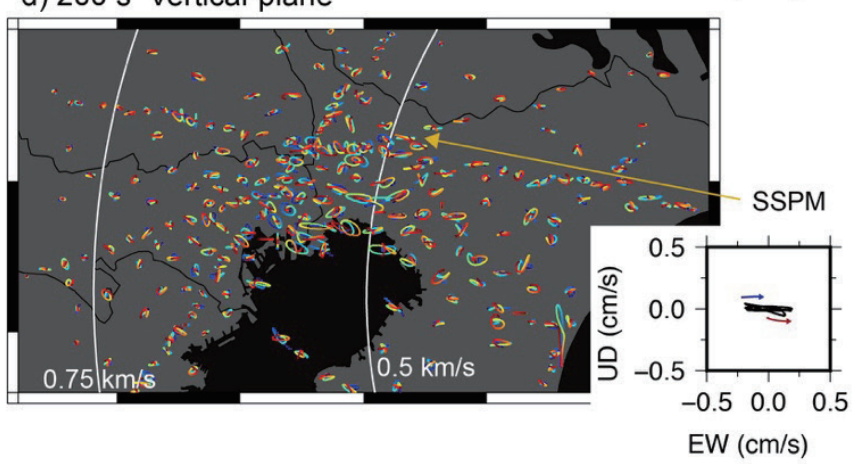

Fig.5 Particle motion of $10 \mathrm{sec}$. records of 55 - 65 (a, b) and 195 - $205 \mathrm{sec}$. (c, d). Horizontal motion (NS-EW) is plotted in a) and c), while the b) and d) show the motion in vertical (UD-EW) plane. Early part of each $10 \mathrm{sec}$. is colored by blue and later part is colored by red.

のブランチと，カーブを描く表面波の存在は, Boué et al. (2016) 11) でも確認された通りである。この実地震記録により, 銚子市付近の 地震によって生じた盆地端部生成波もカーブを描いて伝播する特徵 が理解できる。

\section{3 地震動のスナップショット}

2020 年 6 月 25 日銚子市付近の地震について, 周期 1-10 秒の 3 成分地震波運動エネルギーの平方根を 10 か 20 秒ごとに計算したス ナップショット(Boué et al., 2016 11))を Fig.4 に示している。なお平 野外の記録は平野の地震動を理解する助けとなるため, スナップシ ヨットの作成には K-NET, KiK-net ${ }^{4)}$ と SK-net ${ }^{13)}$ の観測記録も使用 した。しかしそれらの観測点では 2 分間以上はほとんど記録されて いないか公開されてはいないので, トリガー後 120 秒以降はほとん どが平野内に位置する MeSO-netの記録しか存在しない。Fig.4 a) では, 震源から速度 $3 \mathrm{~km} / \mathrm{s}$ で伝播した直達 $\mathrm{S}$ 波が関東平野西端部 に到達し, その後西へ進まず, HTL により盆地端部生成波となり, それが震源方向に向かって逆戻りする様子がうかがえる（Fig.4a 中 央と右, 白色矢印)。また, 東から速度 $1 \mathrm{~km} / \mathrm{s}$ でゆっくりと関東平 野に進入して伝わる直達レイリー波の高次モードがみられる

(Fig.4a 中央と右, 藍色矢印)。これは, 次節に示寸粒子軌跡と, 付 録 Fig.A2b に示寸表面波伝播速度からの推定による。なお，千葉県 の東京湾沿岸部で $\mathrm{S}$ 波到達後, レイリー波到達前に大きくなってい る(Fig.4a 各図, “S-coda wave”の部分)。Fig.4 には全国一次地下構 造モデル(JIVSM; Koketsu et al., 2009 14))による地震基盤深さをコ ンターで示しているとおり, 関東平野の中でも特に深い構造の部分 であることから, 深い盆地構造に滞留している S 波コーダと考えら れる。これも後述のシミュレーション結果から理解できる。
Fig.4 b)では, 盆地端部生成波が東向きに方向を変えて, 表面波速 度の $0.5 \mathrm{~km} / \mathrm{s}$ でゆっくり伝播したラブ波が, 地震発生 200 秒前後 に, 震源直上から西に向かって直接伝播してきた直達ラブ波と融合 する様子がうかがえる。

\section{4 地震動の粒子軌跡}

先ほどのスナップショットでは，地震波エネルギーが伝播する様 子がうかがえたが，地震波の特性を調べるために，粒子軌跡の分析 を行う。Fig.5 には 2020 年 6 月 25 日の銚子市付近地震の地震発生 60 秒後と 200 秒後の前後 10 秒間の周期 3-9 秒の粒子軌跡を描いて いる。6 0 秒後には，関東平野西端部の HTL で盆地端部生成波が生 じている。その粒子軌跡はおよそ南北方向となっており，上下動が 小さいことから，盆地端部生成波は，表面波のラブ波であると考え られる。なお, 関東平野東部において速度 $1 \mathrm{~km} / \mathrm{s}$ で震源から伝播し てきた地震波の粒子軌跡が，波面に直行していることと，上下方向 にも動いていてプログレードの楕円を描いていることから，レイリ 一波の高次モードであることがわかる(付録 Fig.A2c 参照)。千葉県 中央は前述のとおり $\mathrm{S}$ 波コーダと考えられ，複雑な軌跡を描いてい ることからも散乱した波であることがうかがえる。

速度 $0.5 \mathrm{~km} / \mathrm{s}$ 程度でそれぞれ関東平野西部と東部から互いに向 き合って伝播してきた盆地端部生成表面波と直達表面波が融合する のが 200 秒後である。このとき, 東京低地から千葉県北西部にかけ て南北方向に地震動が大きくなっており, 上下動もほとんどないこ とからラブ波が卓越していると考えられる。

3. 地震動の数值シミュレーション 3.12020 年 6 月 25 日銚子市付近の地震動シミュレーション 
盆地端部生成波や転換波に関する数值シミュレーションの研究は 数多く行われており, 単純な速度構造モデルを有する盆地端部効果 についてはいくつもの優れた報告があるのでそれらに譲りたい(例 えば, Kawase and Aki, 1989 3); Pitarka et al., 1996 15); 永野・山 田, $\left.2002{ }^{16)}\right)$ 。ここでは, 実際に関東平野で観測された盆地端部生成 波の生成メカニズムと伝播特性を探ることを目的にして, 現実的な 複雑な速度構造モデルを用いた数值シミュレーションを行う。

Fig. 6 b)は, JIVSM ${ }^{14)}$ による, 関東平野の 2 次元断面図を示してい る。2020年 6 月 25 日銚子市付近の地震の震源位置である北緯 35.55 度の 2 次元速度構造モデルを切り出した(Fig.1 参照)。関東平野西端 部において，八王子構造線 HTL が急峻な基盤構造を形成している ことがわかる。HTL から東に向かって, $V_{S}$ が $0.5 \mathrm{~km} / \mathrm{s}, 0.9 \mathrm{~km} / \mathrm{s}$, $1.5 \mathrm{~km} / \mathrm{s}$ の層が徐々に深くなっており, 平野中央では地震基盤深度 が $4 \mathrm{~km}$ に達し, 震源位置の銚子市付近では地震基盤が再び浅くな る盆地構造を有している。

2 次元差分法による $\mathrm{SH}$ 波シミュレーションを行った。格子間隔は,

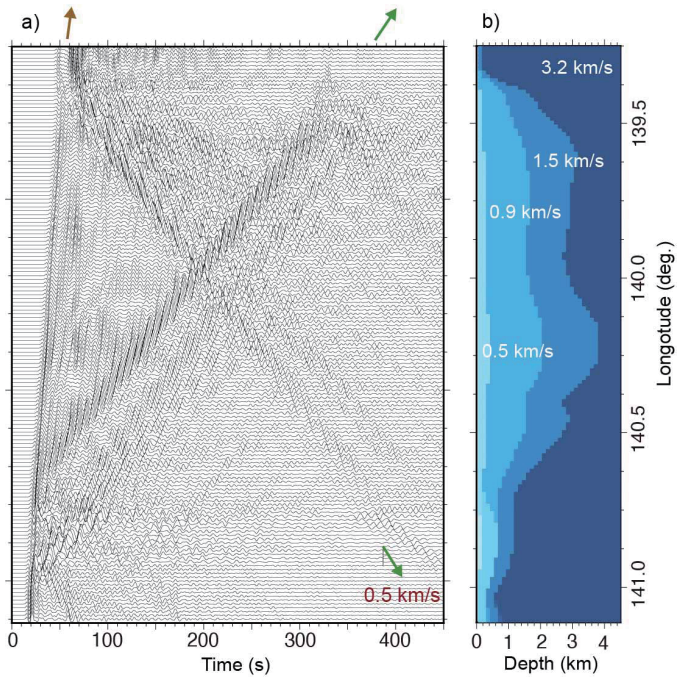

Fig. 6 a) 2D SH wave simulation result for the event of the 2020 M6.0 near Choshi City. Waveform is calculated at surface along the velocity structure model shown in b) extracted from JIVSM ${ }^{14)}$.
水平方向に 0.0125 度で深さ方向に $125 \mathrm{~m}$ である。震源深さは $36 \mathrm{~km}$ で, 震源時間関数は周期 6 秒のリッカー波とした。 2 次元なので線 震源で表現される。地表のシミュレーション波形を Fig. 6 a)に示す。 なお振幅はそれぞれの波形の最大值で規格化されている。銚子市付 近, 太平洋プレートが沈み込む深さ $36 \mathrm{~km}$ で発生した地震は, 初め に大きな振幅を有する $\mathrm{S}$ 波として伝わる。千葉県東京湾岸 $\left(140.125^{\circ} \mathrm{E}\right.$ 付近)では $\mathrm{S}$ 波到達後も振幅が大きくなっており，前述 の $\mathrm{S}$ 波コーダと考えられる。銚子市付近 $\left(140.75^{\circ} \mathrm{E}\right)$ からは直達表面 波と考えられる波が速度およそ $0.5 \mathrm{~km} / \mathrm{s}$ で伝わっており，NS成分 に観測された直達表面波と類似した波動伝播特性を有している。 $\mathrm{S}$ 波が HTL に到達した後，逆方向に伝播する波が発生しており，観 測波形にも見られた盆地端部生成波がシミュレーションによっても 同様に生じていることがわかる。その伝播速度から表面波と考えら れるが，いくつかのブランチが見られたりして，観測された波動伝 播特性を完全には再現できていない。

\section{2 盆地端部構造の影響}

観測波形とシミュレーション波形の差異については, 3 次元速度 構造を考慮した 3 次元シミュレーションを行うことで改善される可 能性もあるが，ここでは完璧な再現シミュレーションを目的として いるのではなく, シミュレーションによって盆地端部の影響につい て検討することが目的である。JIVSM 14)では関東平野の堆積層地下 構造モデルを構築しているが, 盆地端部のモデル化が容易でないこ とは知られており, 盆地端部モデル化精度がシミュレーション結果 に大きく影響する可能性がある。単純な盆地端部構造モデルがエッ ジ効果に与える影響の検討は上述の通り数多く行われている。ここ では, HTL の現実的な複雑な盆地端部構造モデルが盆地端部生成波 へ与える影響を検討するために，JIVSM 14)から HTL のいくつかの 断面を切り出した。異なる緯度で切り出した構造モデルを Fig.7 に 示している。これらの 2 次元断面による $\mathrm{SH}$ 波のシミュレーション を先ほどと同様に行う。構造モデル以外の計算条件は同じである。

北緯 35.45 度の速度構造モデルの場合 (Fig.7 a), 最も急峻な盆地 端部を有した深い盆地構造であるためか，盆地端部生成波と直達表 面波が効率的に発生し，Kawase and Aki (1989)にみられるような 盆地内を行き来する波動伝播が確認できる。北緯 35.85 度のモデル
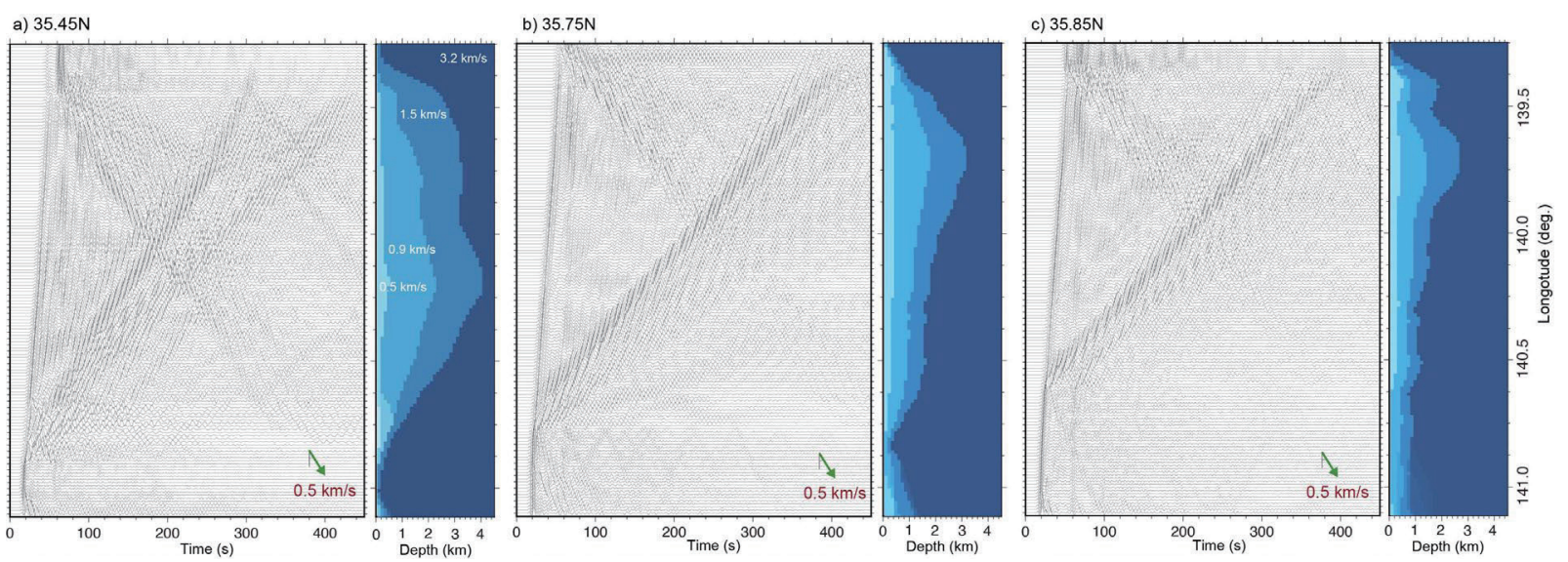

Fig.7 2D SH wave simulation result for several velocity structure models. Waveform is calculated at surface along the velocity structure model shown in right, that is extracted from JIVSM ${ }^{14}$ model at the latitudes of a) $35.45^{\circ}$, b) $35.75^{\circ}$ and c) $35.85^{\circ}$ North. 
は(Fig.7 c), 盆地端部で単調に深くなるモデルではなく複雑な構造 を有している。そのためか, 盆地端部周辺では生成波が大きな振幅 を持っているが, エネルギーが大きな時間が長く, あまり遠くまで は伝わらない。35.75 度のモデル(Fig.7 b)も 35.85 度のモデルと似 ている。これらは, $0.5 \mathrm{~km} / \mathrm{s}$ の層が厚いためか, 直達表面波の伝播 速度が遅い。しかし, 盆地端部生成波はあまり大きくならず, 平野 を横断する途中でほぼ消滅する。実際の観測波形は, これらのモデ ルにより構成された 3 次元構造を有しているため, それぞれの特徵 が反映されたものになっていると考えられる。また, 盆地端部生成 波の生成位置がそれぞれのモデルで異なっているが, これも, モデ ルの端部構造と関係しているように見える。このように計算モデル の違いが, シミュレートされた盆地端部生成波の伝播特性を変化さ せることは興味深く, 現在課題となっている盆地端部の高精度なモ デル化のためには, 盆地端部の地下構造そのものを調べること以外 にも, 平野内部で観測される盆地端部生成波の伝播特性から推定す ることも可能であるといえる。

\section{3 震源深さの影響}

すでに指摘したことであるが，実際に観測された地震波形には， 明瞭な盆地端部生成波が見える一方で, 盆地端部転換波は見えにく かったことは, Boué et al. (2016) 11)に示された地震波干渉法により 合成された仮想地震記録と相反している。その違いの原因の一つと して震源深さの違いを挙げた。そこで, 震源深さの違いによる影響 を調べるために, いくつかの深さでシミュレーションした結果を Fig.8 に示している。

地表震源の場合(Fig.8 a；D 0 km), S 波はほとんど観測されず, 直達表面波が卓越する。したがって $\mathrm{S}$ 波による盆地端部生成波はか なり小さい。直達表面波は Boué et al. (2016) 11)による仮想地震記 録に比べて速度が遅いため, 盆地内の速度構造モデルの修正が必要 であると考えられる。

震源深さが $20 \mathrm{~km}$ になると, 先ほどの震源深さ $36 \mathrm{~km}$ のシミュ レーションにおいて確認された $\mathrm{S}$ 波とその盆地端部生成波が同様に 見られるが(Fig.8, 緑色矢印), $36 \mathrm{~km}$ のものよりも盆地端部生成波 が遠くまで伝播しない。一方, 震源深さが実際よりも梁い $60 \mathrm{~km}$ や
$80 \mathrm{~km}$ では, 直達表面波の励起が小さい。そして盆地端部生成波は $\mathrm{S}$ 波よりも大きくなっており, 深いほど遠くまで伝播している。こ れらの検討により, 震源深さが盆地端部生成波の生成に寄与寸るこ とや, 最大振幅を観測する波の種類が震源深さにより異なることが わかった。

\section{4. 盆地端部生成波の応答特性}

長周期成分が卓越しや寸い表面波は, 長周期構造物の応答に大き く影響するため, その伝播特性を理解しておくことは工学的に重要 である。今回観測された地震記録は, 関東平野の東方沖で発生した 地震が $\mathrm{S}$ 波として平野内を伝播したのち, 関東平野西端部において 表面波を生成し, 平野内を逆戻りして平野東部にまで伝播する長時 間の地震動である。その間には, 震源直上で生成された直達表面波 が非常に遅い速度で西に向かって伝わり, さらに西端部で転換波と して同様に平野内を逆戻りする。しかも高次モードの表面波も観測 されている。これらの地震波は 5 分間以上にわたって継続している。 ところが，K-NET 7)や SK-net 13)など公開されている強震観測記録 は, 記録時間が 2 分程度のものが多い。ここで示した地震について も, MeSO-net 以外の観測網による強震記録は, S 波でトリガーし た 2 分間の記録が多いが, 都心部ではちょうど 2 分後に盆地端部生 成表面波が到達するため, 計測されていない場合があったり, $\mathrm{S}$ 波 と同じ程度の振幅を有する直達表面波はほぼ計測されていないか, 少なくとも公開はされていない。そこで, MeSO-net で観測された 5 分間以上にもわたる様々な地震波の到来が長周期地震応答特性に どのような影響を及ぼすか検討する。

Fig.9 にはFig.1 に示した 4 つの観測点の速度波形を示している。 さらに, トランスバース方向である NS 成分についてマルチプルフ イルタ解析をした。千葉県北西部の白井市の観測点(SR2M)は, 震源 からおよそ $100 \mathrm{~km}$ に位置し, 約 210 秒において大きな波群が到達 している。これは震源からの直達ラブ波が, HTLで生成されて平野 内を逆戻りしてきた盆地端部生成ラブ波とちょうど交わる時間であ る。マルチプルフィルタ解析により, 地震発生 30 秒後に到達する 直達 $\mathrm{S}$ 波は広帯域にパワーを有し, 特に周期 1 秒程度で大きいこと がわかる。一方, 210 秒後の波は, 周期 3-4 秒で大きくなっている
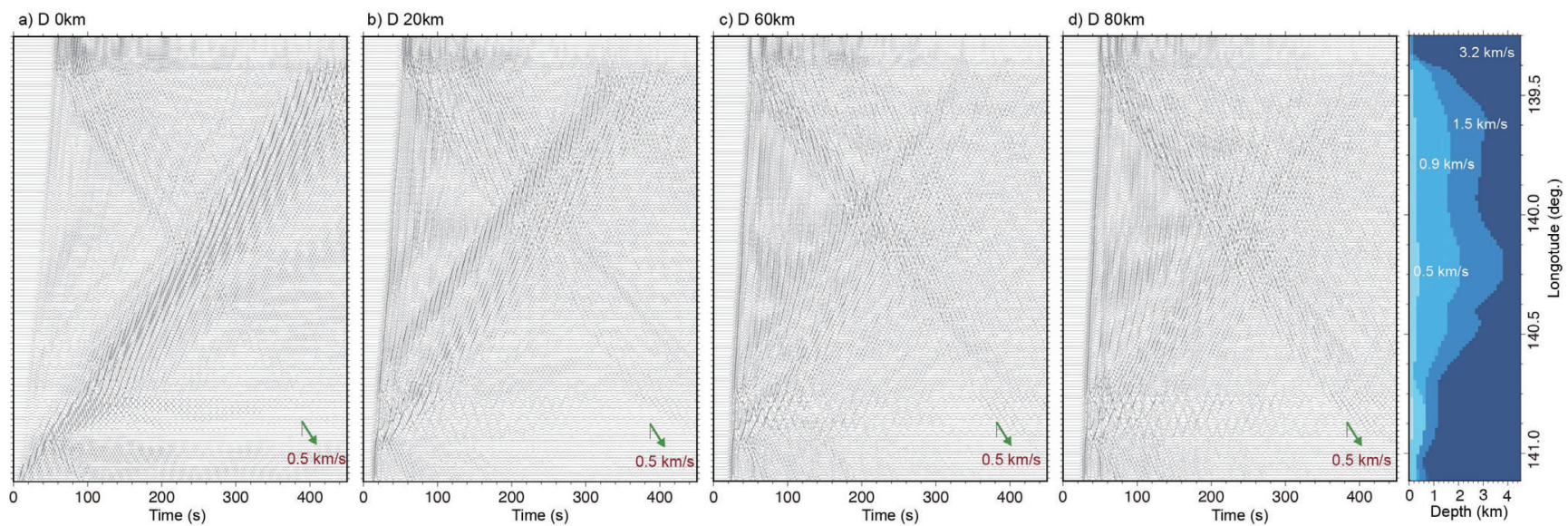

Fig.8 2D SH wave simulation result for the source depths of $0,20,60$ and $80 \mathrm{~km}$. Waveform is calculated at surface along the velocity structure model shown in right, same with Fig.6 b). 


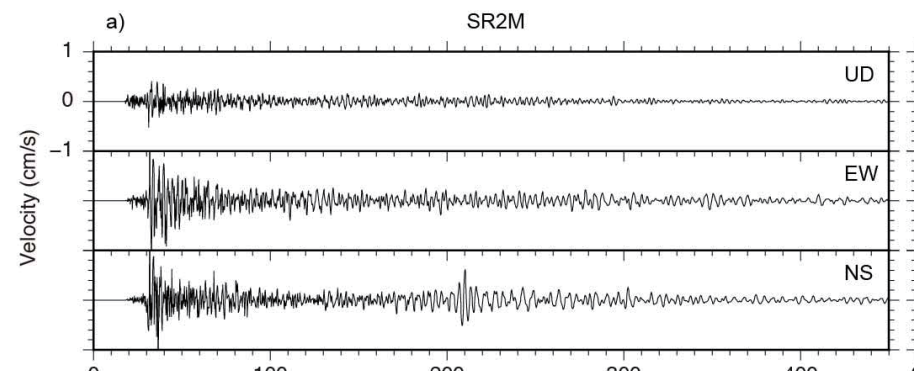

b) TKNM
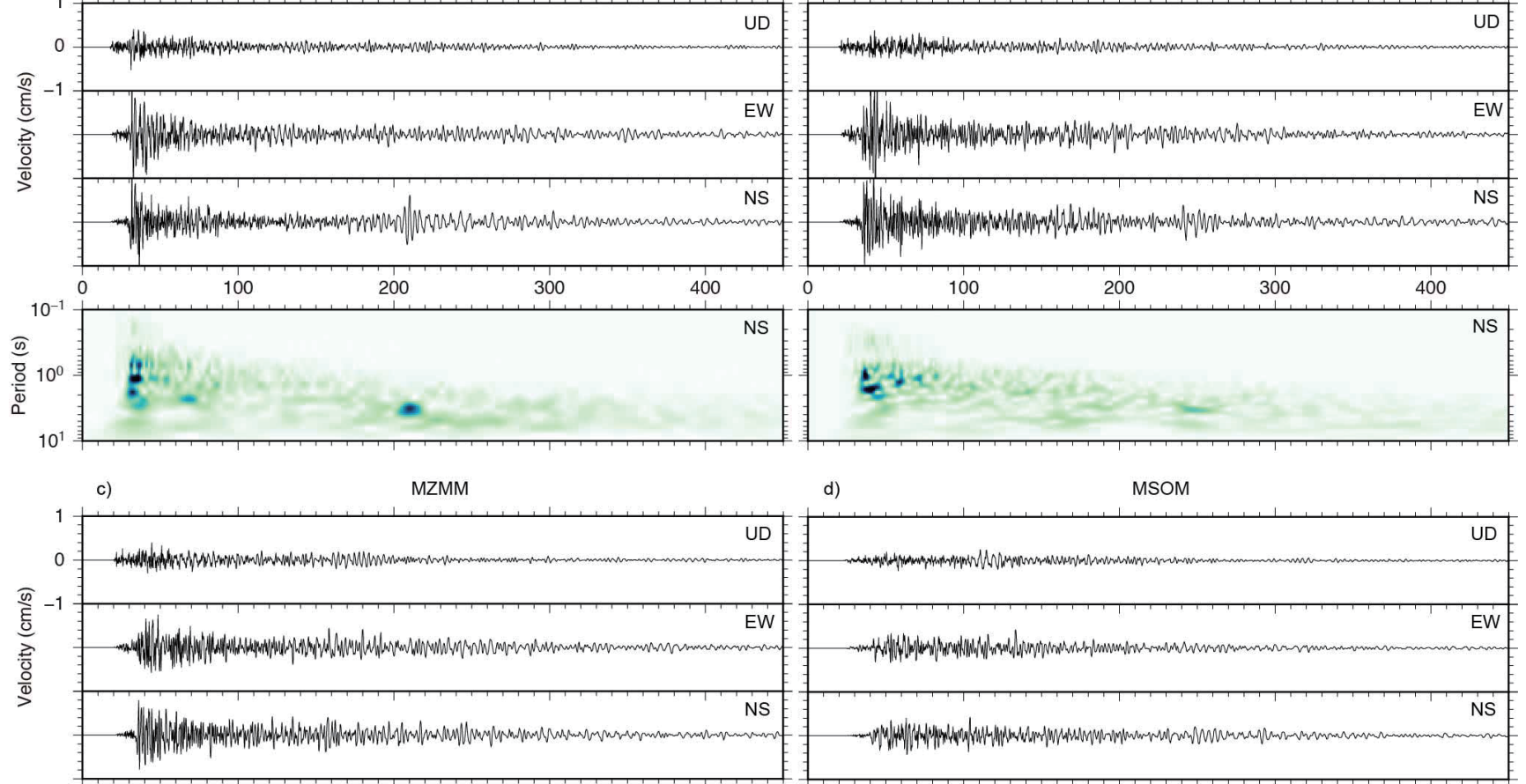

d)

MSOM
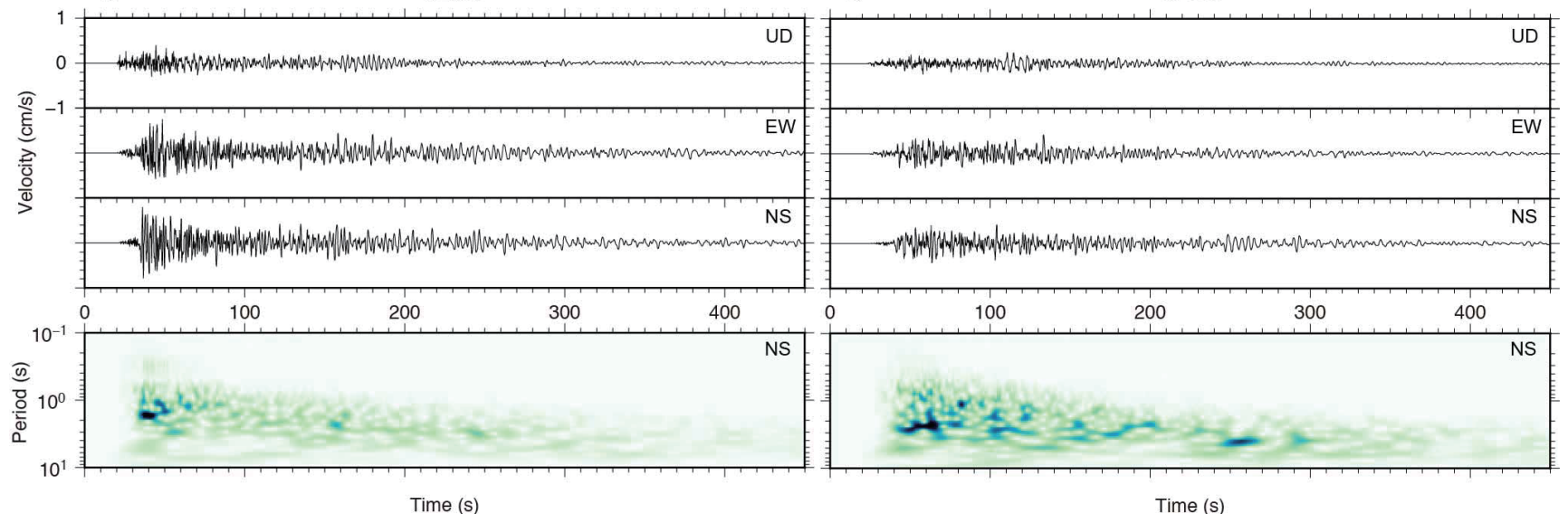

$\begin{array}{lllll} & 100 & 200 & 300 & 400\end{array}$

Fig.9 Velocity waveform and its spectrogram estimated by multiple filter analysis at four selected stations shown in Fig. 1 a), located at the northwestern part of Chiba Prefecture (a; SR2M), Misato City (c; MZMM) and Kanamachi, Katsushika Ward (b; TKNM) in the Tokyo lowland area and Suginami Ward (d; MSOM) at Musashino Plateau. NS component was used for multiple filter analysis.

ことから長周期成分が卓越した表面波といえる。震源から約 $120 \mathrm{~km}$ 離れた東京低地の葛飾区金町(MZMM) と埼玉県三郷市(TKNM)では, NS 成分において $\mathrm{S}$ 波のほかに約 170 秒後と約 240 秒後において速 度波形と, その長周期成分が大きくなっている。これらは, 盆地端 部生成ラブ波と，直達ラブ波の到来時刻にそれぞれ対応している。 震央距離約 $130 \mathrm{~km}$ の東京 23 区西部に位置する杉並区高井戸 (MSOM)では, 直達 $\mathrm{S}$ 波が他に比べて小さくなっており, 高周波成
分が減衰している。ここでは約 100 秒後に盆地端部生成表面波が到 達するため, $\mathrm{S}$ 波到達後から長周期成分が卓越している。さらに 260 秒後には直達ラブ波が到達しているため, 長い時間にわたって長周 期地震動が観測されている。

この章の冒頭に述べたとおり，他の強震観測網で得られた記録は 2 分程度で終了しているものがほとんどである。そのため，その記 録により推定される建物応答は, 実際の応答よりも小さくなる可能 a)

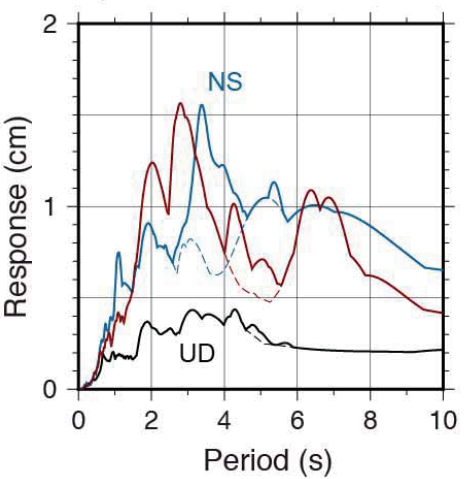

b)

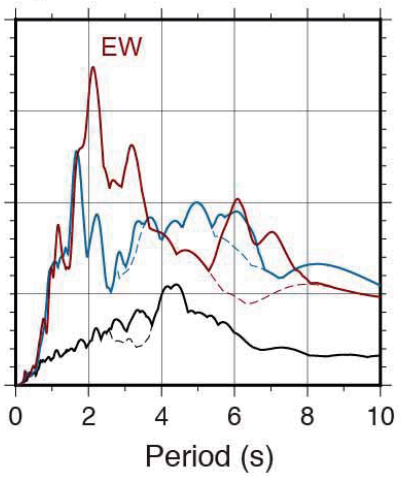

c)

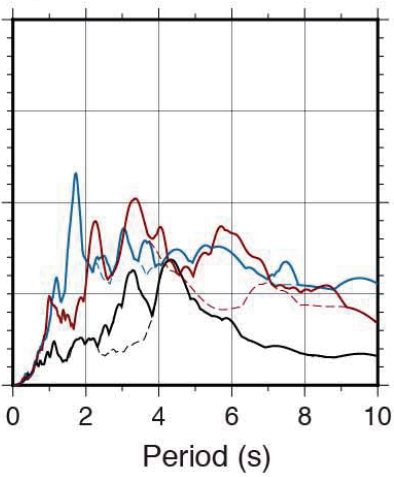

d) MSOM

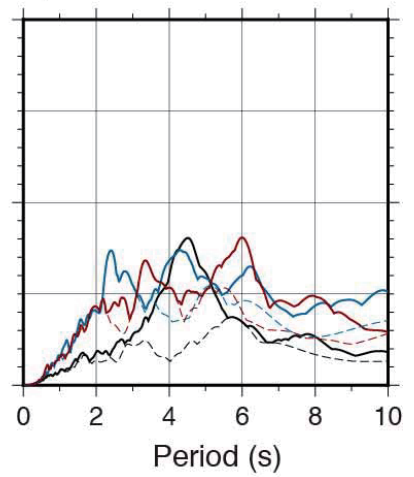

Fig.10 Displacement response spectrum of $5 \%$ damping SDOF system at the stations shown in Figs.1a and 9, calculated for the components of UD (black), NS (blue) and EW (red). Solid line indicates the spectrum calculated using whole record during the event (10 minutes from origin time), while broken line was calculated only using the record with a duration of 2 minutes from the origin time. 
性がある。強震動予測においては, ここで示したような中地震の観 測記録をもとに経験的に評価することも多いので, 使用する地震記 録長によって予測結果が過小評価にならないように気をつけなれば ならない。

地震記録長が応答の推定結果に与える影響を調べるために, MeSO-netによる十分な長さの記録と, そのうち地震発生後 2 分間 の記録により推定した変位応答スペクトルを Fig.10に示す。減衰は $5 \%$ とした。千葉県北西部 SR2M 観測点の NS 成分において 210 秒 後に明瞭に見られる地震波は, 周期 3-4 秒に大きなパワーを持って おり, 最大応答変位は $1.5 \mathrm{~cm}$ ほどになる。しかし，もしも記録が 2 分間しかなければ応答変位は $0.7 \mathrm{~cm}$ 程度と推定され, 半分に過小 評価される。東京低地の TKNM と MZMM は, NS 成分の 170 秒後 と 240 秒後に長周期成分の表面波が確認されたが，その応答は大き くならないのか，2 分間の応答とほとんど変わらない。ところが， 波形では明瞭には確認できないものの, EW 成分において周期 6 秒 で約 2 倍の応答が後続波により推定されている。東京都杉並区の MSOM においては, 盆地端部生成表面波は 2 分間の記録に含まれ ている。ところが，4 分も経過してから直達表面波が到達し，それ は周期 4 秒ほどにパワーを持っており, それによるものなのか周期 4 秒以上においては NS 成分と $\mathrm{EW}$ 成分においても長周期の応答が 3 割ほど大きくなっている。さらにこれまであまり着目してこなか った上下動成分が，周期 4 秒において 4 倍以上になっている。

この地震を例として, 連続観測が重要であることに改めて気づかさ れるが，その重要性については座間(2009)17)により指摘されていた とおりで,「長周期地震動の後続位相を記録しない場合があるため, トリガーに依存しない連続観測や速度型強震計による観測など, 長 周期地震動を考慮した観測も必要」である。それ以外にも, ポス卜 トリガー記録長の設定を長くするといったソフト的な対応でも可能 と考えられる。それに合わせて, 計算負荷が大きい時刻歴応答解析 を実施する時間についても適切に評価しなければならない。

ここで示した $M 6.0$ の地震による応答は高々数 $\mathrm{cm}$ であるが, 今 後発生する可能性がある千葉県東方沖地震や, 房総沖地震のような 大地震が発生すれば, 長周期地震動は地震の $M$ に比例して単純に大 きくなることを考えると, 震源位置によっては直達波だけでなく, 盆地端部生成波が長周期の応答に与える影響を看過するわけにはい かない。最悪の場合, 直達表面波と盆地端部生成表面波が都心部で 増幅的に干渉寸ることも起こりうるし，首都圈西部では，エッジ効 果により「震災の帯」が形成されることも想定される。首都圈西部 はベッドタウンの役割を果たしているが，近年では高層マンション も建設されていることから, 都心と同じ程度かそれ以上に長周期地 震動への対策が望ましいことが実際の地震観測記録により明らかに なった。

\section{5. まとめ}

首都圈に高密度に配置された MeSO-net の連続地震観測により, 関東平野の東方沖で発生した地震波が平野西端部において直達 $\mathrm{S}$ 波 から盆地端部生成波を生み出し, それが表面波として長い時間をか けて平野内を逆戻りして震源方向に向から様子が明瞭に捉えられた。 さらに直達表面波が 5 分以上かけて平野西端へ横断寸る様子が見ら れ，それが盆地端部転換波として同様に平野内を逆戻りする様子も
捉えられた。このような波動伝播の特性は, 関東平野のスナップシ ヨットにより空間的にも確認できる。紀伊半島沖地震や新潟県中越 地震では, 表面波として関東平野に進入した波が盆地端部転換波と して平野内を伝播する様子が確認されているが，このように盆地端 部生成波が伝播方向を 180 度变えて平野内を逆戻りして伝播する様 子を実際の地震観測波形により確認したのは初めてであろう。これ は, 高密度連続地震観測を行っている MeSO-netにより可能となっ たことである。

トランスバース成分は基本モードのラブ波が卓越するが，上下動 成分には，レイリー波の高次モードが現れ，これも盆地端部で転換 する。これらのモードの識別は, 関東平野の地震動の粒子軌跡によ り明らかにした。盆地端部で生成したり転換したりした表面波は 徐々に速度を落と寸ため，その波動伝播は緩やかなカーブを描く。 このことは関東平野の西方で発生した地震の観測記録にも見られ, 関東平野内の速度構造の変化によるものと考えられる。

観測された波動伝播特性についての理解を深めるために, 数値シ ミュレーションを実施した。大きな振幅を持つ直達 $\mathrm{S}$ 波と, それが 平野西端部で生成した表面波，そして直達表面波が合成され，それ らの伝播特性も観測されたものと大局的には類似している。しかし 細かな特性については異なっているところもあることから，その原 因を調べるために，いくつかの速度構造モデルによるシミュレーシ ヨンを試みた。その結果, モデルの盆地端部形状が盆地端部生成波 の生成と伝播に大きく影響することと, 盆地内部構造が盆地内を伝 播する表面波の伝播特性に影響することがわかった。さらに，震源 深さが浅いと盆地端部生成波が生じにくいことがわかった。

速度波形では直達 $\mathrm{S}$ 波が最大振幅となっている観測点がほとんど であるが，後続の直達表面波や，盆地端部生成表面波は長周期帯域 に大きなパワーを有している。そこで，建物応答に後続波が与える 影響を調べたところ, 周期 2 秒以下では最大応答変位には変化が見 られなかった。一方，後続波を含めた場合には，最大応答変位が 2 倍にもなる場合があることがわかった。トリガー式の強震観測では 後続波まで十分に記録されないことがあるので，長時間かけて伝播 する表面波による建物応答を適切に評価するためには，連続観測記 録が重要であることが改めてわかった。

MeSO-net が構築されて 10 年ほど経過し, 地震記録が蓄積され つつあり, 最近のデータは, NIED により即時公開されている。 MeSO-netやHi-net の連続データは, 地震学の分野で主に利用され ているのが現状であるが，このように高品質な強震記録が得られて いることからも工学の分野への活用が望まれる。このほかにも特徴 的な地震波伝播特性が観測されるかもしれないので, さらなる地震 観測記録の蓄積を待ちたい。また，現在の強震観測は，より長い時 間の記録をすることによって，大規模堆積平野の地盤震動特性につ いて理解が深まることが期待される。

\section{謝辞}

MeSO-net (NIED, 2021) 18)，K-NET 4)，KiK-net 4)および SK-net 13)の記録を使用しました。作図には GMT 19)を使用しました。貴重 なご意見をいただいた匿名查読者の方々に記して感謝いたします。 
参考文献

1) Kawase, H. : Review : Amplification of Seismic Waves by Sedimentary Layers and Its Simulation, Zisin Second Series, Vol. 46, No.2, pp. 171190. 1993 (in Japanese)

川瀬博：表層地質による地震波の増幅とそのシミュレーション, 地震 第 2 輯, Vol. 46, No. 2, pp. 171-190, 1993

2) Kawase, H. : The cause of the damage belt in Kobe : "The basin-edge effect," constructive interference of the direct S-wave with the basininduced diffracted/Rayleigh waves, Seism. Res. Lett., Vol. 67, No. 5, pp. 25-34, 1996

3) Kawase, H. and K. Aki : A study on the response of a soft basin for incident S, P, and Rayleigh waves with special reference to the long duration observed in Mexico City, Bull. Seism. Soc. Am., Vol. 79, pp. 1361-1382, 1989

4) National Research Institute for Earth Science and Disaster Resilience : NIED K-NET, KiK-net, National Research Institute for Earth Science and Disaster Resilience, doi:10.17598/NIED.0004, 2019

5) Miyake, H., K. Koketsu : Long-period ground motions from a large offshore earthquake: The case of the 2004 off the Kii peninsula earthquake, Japan, Earth Planets Space, Vol. 57, pp. 203-207, 2005

6) Furumura, T. and T. Hayakawa : Anomalous Propagation of LongPeriod Ground Motions Recorded in Tokyo during the 23 October 2004 Mw 6.6 Niigata-ken Chuetsu, Japan, Earthquake, Bull. Seism. Soc. Am., Vol. 97, No. 3, pp. 863-880, 2007

7) Aoi, S., Y. Asano, T. Kunugi, : MOWLAS : NIED observation network for earthquake, tsunami and volcano, Vol. 72, p. 126, Earth Planets Space, 2020

8) Sakai, S., N. Hirata : Distribution of the Metropolitan Seismic Observation Network, Bull. Earthquake Res. Inst. Univ. Tokyo, Vol. 84, pp. 57-69, 2009 (in Japanese)

酒井慎一, 平田直 : 首都圈地震観測網の設置計画, 地震研究所彙報, Vol. 84, pp. 57-69, 2009

9) Denolle, M. A., H. Miyake, S. Nakagawa, N. Hirata and G. C. Beroza : Long-period seismic amplification in the Kanto Basin from the ambient seismic field, Geophys. Res. Lett., Vol. 41, pp. 2319-2325, 2014

10) Viens, L., K. Koketsu, H. Miyake, S. Sakai, and S. Nakagawa : Basinscale Green's functions from the ambient seismic field recorded by MeSO-net stations, J. Geophys. Res. Solid Earth, Vol. 121, pp. 25072520, 2016

11) Boué, P., M. Denolle, N. Hirata, S. Nakagawa, G. C. Beroza : Beyond basin resonance: characterizing wave propagation using a dense array and the ambient seismic field, Geophys. J. Int., Vol. 206, Issue 2, pp. 1261-1272, 2016.8

12) Forgani, F. and R. Snieder : Underestimation of body waves and feasibility of surface-wave reconstruction by seismic interferometry, The Leading Edge, Vol. 29, No. 7, pp.790-794, 2010

13) Takano, K. and M. Uehara : Current Status of Data Collection in the Seismic Kanto Strong Motion Network in Metropolitan Area : SK-net, Technical Research Report, Earthquake Research Institute, The University of Tokyo, No.20, pp. 1-10, 2014 (in Japanese) 鷹野澄, 上原美貴 : 首都圈強震動総合ネットワーク SK-net におけるデー 夕収集の現状, 東京大学地震研究所技術研究報告, No. 20, pp. 1-10, 2014

14) Koketsu, K., H. Miyake, and H. Suzuki : Japan Integrated Velocity Structure Model Version 1, Proc. World Conf. Earthq. Eng., Paper No. 1773, 2012

15) Pitarka, A., K. Irikura, T. Iwata, and T. Kagawa, : Basin Structure Effects in the Kobe Area Inferred from the Modeling of Ground Motions from Two Aftershocks of the January 17, 1995, Hyogo-ken Nanbu Earthquake, Journal of Physics of the Earth, Vol. 44, Issue 5, pp. 563576,1996

16) Nagano, M. and A. Yamada : Amplification Characteristics of Ground Motions adjacent to Basin-edge Structure, Journal of Structural and Construction Engineering (Transactions of AIJ), Vol. 67, No. 560, pp. 5158, 2002.10 (in Japanese)

永野正行, 山田有孝 : 3 次元盆地端部構造の境界近傍における地震動増幅 特性, 日本建築学会構造系論文集, Vol. 67, No. 560, pp. 51-58, 2002.10
17) Zama, S. : Long-Period Strong Ground Motion, Zisin Second Series, Vol. 46, No. 3, pp. 329-342, 1993 (in Japanese)

座間信作 : やや長周期の地震動, 地震 第 2 輯, Vol. 46, No.3, pp. 329-342, 1993

18) National Research Institute for Earth Science and Disaster Resilience : NIED MeSO-net, National Research Institute for Earth Science and Disaster Resilience, https://doi.org/10.17598/NIED.0023, 2021 (accessed 2021.4.9)

19) Wessel, P., W. H. F. Smith, R. Scharroo, J. Luis, F. Wobbe : Generic mapping tools: improved version released, Eos Trans AGU, 94, 45, pp. 409-410, 2013

\section{付録}

南部域のほぼ中央に位置する東京湾岸 $\left(139.8^{\circ} \mathrm{E} / 35.55^{\circ} \mathrm{N} ;\right.$ Fig.1)における JIVSM ${ }^{14)}$ によるモデルにより計算したラブ波(Fig. A1)とレイリー波のミデ イアムレスポンスと群速度，およびレイリー波の楕円率を示している(Fig. $\mathrm{A} 2)$ 。ラブ波はほとんどの周期帯域において基本モードが卓越する。周期 3 秒程度で一次モードが大きくなるものの, その群速度は基本モードのものと 同程度である。レイリー波は周期 5 秒以上において一次モードが基本モード よりも大きい。周期 4-5 秒では基本モードが卓越し，その群速度は $0.5 \mathrm{~km} / \mathrm{s}$ 程度である。そして棈円率は負であることから，レトログレードの楕円を描 く。その絶対值は小さくなることから，水平動に比べて上下動が卓越するこ とを意味する。すなわち, 上下動には基本モードと一次モードが多く含まれ ている。一方, 周期 3 秒でも一次モードが卓越し, このときはプログレード を描く。なお，このような表面波の特徵は，同緯度の異なる経度 $\left(139.6^{\circ} \mathrm{E} お\right.$ よび $\left.140.125^{\circ} \mathrm{E}\right)$ でも類似していることを確認している。 a)

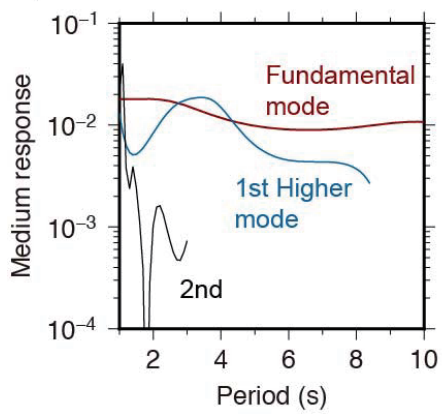

b)

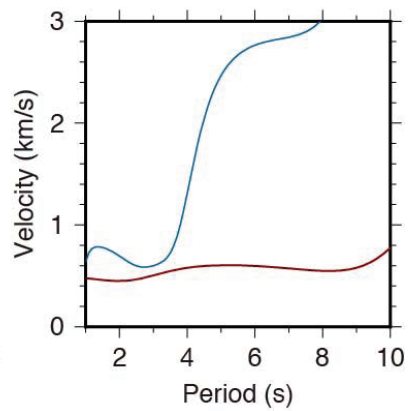

Fig. A1 Medium response a) and group velocity b) of Love wave for the model of JIVSM ${ }^{14)}$ at Tokyo bayside. Fundamental, 1st and 2nd higher modes are shown by red, blue and black lines. 
a)

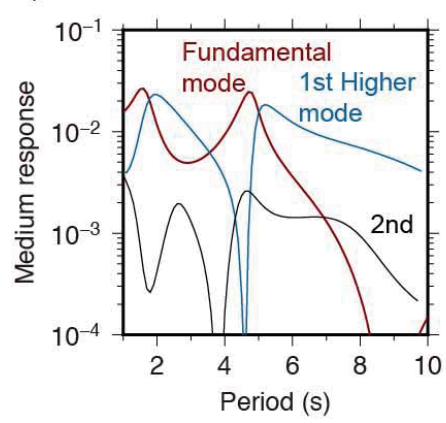

b)

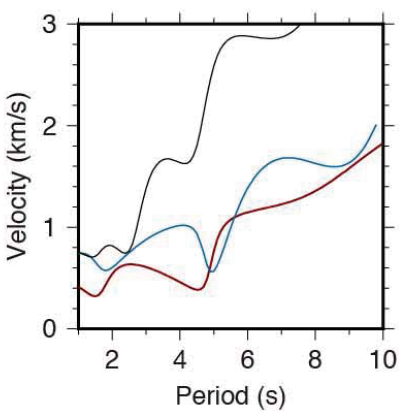

d)

c)

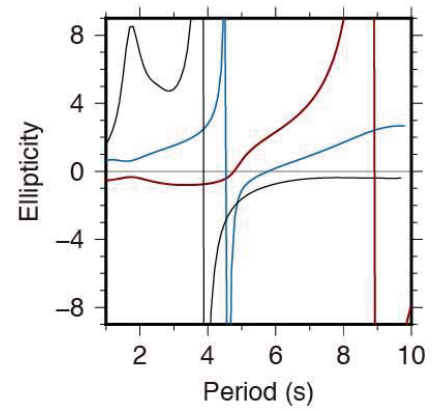

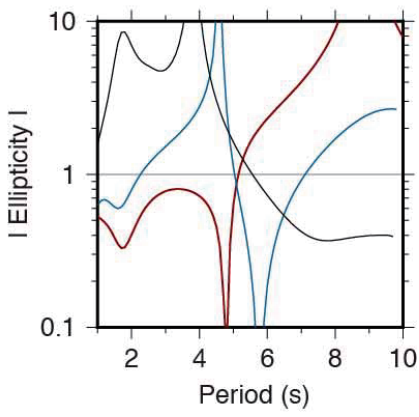

Fig. A2 Medium response a) and group velocity b) of Rayleigh wave for the model of JIVSM ${ }^{14)}$ at Tokyo bayside. Fundamental, 1st and 2nd higher modes are shown by red, blue and black lines. Ellipticity of Rayleigh wave is shown in c) and its absolute value is shown in d). 


\author{
Kosuke CHIMOTO*1 \\ ${ }^{* 1}$ Assoc. Prof., Faculty of Engineering and Design, Kagawa Univ., Dr.Eng.
}

It is known that the large-scale sedimentary basin generates surface wave when the seismic wave arrives at the edge of the basin. Such waves are called basin edge induced wave and basin edge transduced wave. These waves often have a large amplitude and cause a characteristic damage distribution, that was confirmed by the 1995 Kobe earthquake and the 1985 Mexico Michoacan earthquake. The existence of such waves was confirmed by a characteristic damage belt zone and numerical simulations. The basin edge transduced wave has been observed from the ground motion record, while the propagation of the basin edge induced wave has not been observed clearly.

MeSO-net is a seismic observation network recently constructed in the Kanto basin with dense seismic sensor installation inside the basin. One of the features of MeSO-net includes the continuous observation system, which is different from the conventional strong motion observation networks that record only a few minutes after the ground motion was detected. Because the basin edge induced surface wave propagates inside the large basin slower than the direct body wave, it takes more than five minutes to propagate through the basin. I found the ground motion record observed by the MeSO-net includes long duration of surface wave propagating inside the Kanto basin and the basin edge induced wave was also recorded clearly that was generated at the western edge of the Kanto basin.

The snapshot and the particle motion of the MeSO-net record clearly show the marriage of the direct surface wave and the basin edge induced wave in the Tokyo lowland area. It is also found that the higher mode of Rayleigh-wave dominates in the vertical component and the basin edge induced wave mainly consists of the fundamental Love wave. These features were confirmed by the theory of surface waves and a ground motion simulation. The 2D SH wave numerical simulation also generated the basin edge induced wave at the western edge of the Kanto basin and it is merged with the direct surface wave at the central part of the basin. The parametric study revealed that the characteristic of the wave propagation in the Kanto basin is much affected by the structure of the basin edge. It was also found that the source depth also influences the wave propagation characteristic in the Kanto basin.

The multiple filter analysis showed that the direct $\mathrm{S}$-wave has a power at the broad period range while the later phases consisted by the direct surface wave and the basin edge induced wave has a power at a long period range. I found such a complex wave propagation characteristic increases the building response. When I use a short duration of ground motion record, that is generally provided by the strong motion record, the maximum displacement response sometimes exhibits low value of response, while it becomes large value when I use more than five minutes record observed by MeSO-net. 